
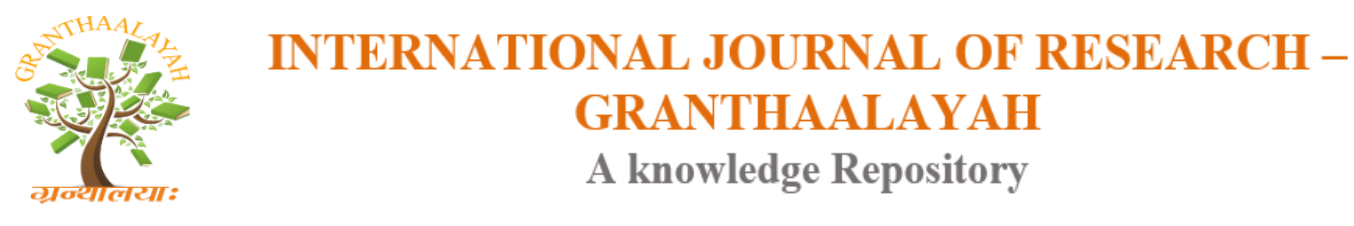

Social

\title{
A STUDY ON THE REASONS OF FAILING IN ACCOUNTING COURSE AND THE TEACHING TECHNICS FOR LEARNING ACCOUNTING BETTER
}

\author{
Filiz Angay Kutluk *1, Adnan Dönmez ${ }^{2}$, Kürşad Çavuşoğlu ${ }^{3}$ \\ ${ }^{* 1}$ Akdeniz University, Faculty of Applied Sciences, Antalya, Turkey \\ ${ }^{2}$ Akdeniz University, Faculty of Economics and Administrative Sciences, Antalya, Turkey \\ ${ }^{3}$ Mersin University, Anamur Vocational School, Anamur, Mersin, Turkey
}

\begin{abstract}
Competition is a force to the organizations to generate and apply new strategies to challenge the changing environment. Qualified labour force is also an important constituent in this way. Universities are also in competition to train successful, dynamic, qualified and innovative students who will be the future labour force. Updating the curriculum, searching more understandable teaching techniques and getting feedback from students and lecturers are some ways to be improved and preferable for universities. Each course may require different teaching techniques to be understood. The aim of this study is to investigate the reasons why the students fail in accounting courses and which teaching techniques may help them to understand accounting better. A survey is prepared and applied to the Summer school students who had "Accounting" related lessons in a university to detect the reasons they chose the course in summer school, the reasons that they failed in accounting course during the semester and the teaching techniques that they will better understand the course. The main reasons to fail Accounting lessons were that they didn't study enough and they can't understand accounting. The best method of understanding theoretical part of "Accounting" courses is using blackboard and power-point presentation together; for understanding practical/exercise part of is using blackboard. Most of the students have chosen Summer School to pass the failed courses.
\end{abstract}

Keywords: Accounting Education; Teaching Techniques; Failing in Accounting Course.

Cite This Article: Filiz Angay Kutluk, Adnan Dönmez, and Kürşad Çavuşoğlu. (2018). “A STUDY ON THE REASONS OF FAILING IN ACCOUNTING COURSE AND THE TEACHING TECHNICS FOR LEARNING ACCOUNTING BETTER.” International Journal of Research - Granthaalayah, 6(9), 535-549. https://doi.org/10.5281/zenodo.1465026.

\section{Introduction}

Competition is a force to the organizations to generate and apply new strategies to challenge the changing environment. Qualified labour force is an important constituent in this way. Universities 
are also in competition to train successful, dynamic, qualified and innovative students who will be the future labour force.

Accounting is one of the most important information sources in business life, because accounting knowledge is needed for producing accurate and reliable financial statements and for decision making. Especially management candidates will need accounting information even if they won't be accountants; so the teaching techniques and failure reasons of accounting during undergraduate level should be considered seriously. Universities will gain prestige and be preferred by training well equipped students in this competitive era.

Undergraduate-level accounting courses are generally given in Economics and Administrative Sciences programs and in programs devoted to accounting and finance education in Turkey. Some of the accounting courses are voluntary and some of them are compulsory in these programs. This study is conducted in Akdeniz University, a state university in south of Turkey. There are two academic semesters, Fall and Spring, in formal education each comprises 15 weeks. Students take 30 credits/hours in total in formal education semester; they can also take 15 credits/hours more from the courses that they have failed in previous semesters which are not compulsory attendance. The university has a Summer School Program comprises 5 weeks; so the courses of a formal semester are taken three times a week. Students from other universities can also choose courses from Summer School at Akdeniz University. Students can take totally 12 credits/hours in summer school. The primary reason that students take summer school isto pass the failed courses, but there are also some students who take courses in summer school to graduate earlier.

The aim of this study is to investigate the reasons why the students fail in accounting courses and which teaching techniques may help them to understand accounting better. The following questions will be tried to answer:

1) Is there any relationship between the reason to choose summer school and the reason to fail accounting courses?

2) Is there any relationship between the reason to fail accounting courses and contribution of accounting courses taken in summer school?

3) Is there any relationship between the reason to fail accounting courses and the method to understand the accounting course better?

4)

The remainder of the paper is organized as follows: first, a review of studies about teaching techniques in accounting courses is presented. Next section presents the methodology and findings. The last section presents conclusion.

\subsection{Literature Review}

The aim of Can, Karaca, Akyel and Demirci (2012: 135)'s study was evaluation of the effectiveness of lecturing by using powerpoint presentations in accounting education. According to the results of Can et al. (2012: 135)'s study, the most successful students were taught with blackboard, the less successful students were taught with both a blackboard and power point presentation and just via power point presentations. 
The aim of Gamlath (2007: 133)'s study was determination of evidence suggesting that usage of accounting simulation game led to observed learning outcomes that were significantly different from learning outcomes of traditional methods. Gamlath (2007: 137)'s study found that students taught via accounting simulation game enjoyed their course more than students taught via traditional method and longer exposure in a game-based learning environment led to noticeable changes in attitude and behavior.

Sardela, de Souza Costa and de Souza Gomes (2017: 182)'s study aimed to analyze perceptions of students about usefulness of video production as a tool in accounting teaching. Sardela et al. (2017: 182)'s study showed that students enjoyed the video-production action and they developed their reading, interactivity, group organization, self learning, oratory, planning and leadership skills by making videos.

The purpose of Chiou, Lee, Tien and Wang (2017: 3687)'s study was to search the effectiveness of various concept mapping techniques on the learning accomplishment of senior accounting students and the effect of different learning styles on the learning accomplishment of students that was attained by using various techniques. The results of Chiou et al. (2017: 3687)'s study indicated that CACSB (computer-assisted construct-by-self-concept mapping) and CACOS (computerassisted construct-on-scaffold concept mapping) techniques had more benefit than PAP (paperand-pencil concept mapping) and TTE (traditional textbook exercise) techniques with relation to learning accomplishment of students; PAP technique was better than TTE technique with relation to learning accomplishment of students; CACOS technique had better support for the students with accommodating and converging learning styles, followed by CACBS, PAP and TTE techniques; CACSB affected learning accomplishment of students with assimilating and diverging learning styles the most significantly, followed by CACOS, PAP and TTE.

Altıntaş, Süer, Sarı and Ülker (2014: 196)'s study aimed to specify the influence of usage of poster projects on the motivational and learning process of managerial accounting students and also aimed to compare the views of students about traditional term papers and poster projects. According the results of Altıntaş et al. (2014: 200)'s study, poster projects were preferred by more than half of the students; on the other hand traditional term papers were preferred by $25 \%$ of the students. Altıntaş et al. (2014: 200) stated that poster project seemed to be a pleasurable and effective tool of assessing managerial accounting students from a point of view of students' statements and assessments.

Megeid (2014: 47)'s study aimed to present the findings about espousal of use of blended learning approach in accounting courses. The results of Megeid (2014: 50)'s study indicated that students had overall positive attitude toward blended learning; they were satisfied with blended learning; they assumed responsibility of their learning. According to the results of Megeid (2014: 50)' study, students preferred the blended learning rather than fully online learning because of their perception about the importance of student-instructor interaction and collaboration in the quality assurance of learning.

The purpose of Abeysekera (2015: 310)'s study was to research the preferences of students regarding traditional, interactive and case-study-based group instructional methods in six courses of the accounting curriculum that had different algorithmic pedagogy. The results of Abeysekera (2015: 310)'s study showed that the least preferred method among all courses was the traditional 
instructional method; the most preferred method in high algorithmic courses (financial accounting, finance, business statistics and management accounting courses) was the interactive instructional method; the most preferred method in the management course among two low algorithmic courses was the case-study-based group instructional method; the most preferred methods in the business law course among two low algorithmic courses were the interactive and case-study-based group instructional methods.

Chiang, Nouri and Samantha (2014: 43)'s study aimed to analyze the effect of a user teaching approach and a traditional preparer teaching approach used in the introductory financial accounting course on the grades of student in a subsequent finance course. The results of Chiang et al. (2014: 49)'s study showed that there was no significant difference between grades of students whose introductory financial accounting course used the traditional preparer teaching approach and the user teaching approach. According to Chiang et al. (2014: 49-50), this indicated that teaching approaches regarding introductory financial accounting course had no effect on the student performance in a subsequent finance course.

The aim of Ertan, Yücel and Saraç (2014: 107)'s study was to measure the contribution of the concept map technique, that was employed in accounting courses, to the learning level of the students. According to the results of Ertan et. al (2014: 119)'s study, it could be said that the achievement of the group studying with concept map increased and the subject described in the course was better understood. According to Ertan et. al (2014: 119), this indicated that using concept map technique in accounting issues had a greater contribution to the level of learning of accounting issues than the traditional presentation method.

Inuwa, Abdullah and Hassan (2017:39)'s study aimed to search the impact of cooperative learning on financial accounting achievement across secondary school students. Inuwa et. al (2017: 39) found that the financial accounting achievement of students exposed to the cooperative learning approach was significantly better than the financial accounting achievement of students exposed to the conventional approach.

The aim of Sultanoğlu, Aydoğmuş and Akman (2014: 104)'study was to examine the effect of the use of excel in the financial accounting course on students' academic achievement. The results of Sultanoğlu et. al (2014: 109)' study indicated that the excel application used in financial accounting course had a positive effect on the achievement of the students.

Lubbe (2016: 63)'s study aimed to analyze the effect of the flipped classroom method on the improvement of the learning experience of accounting students at a higher education institution. The results of Lubbe (2016: 63)'s study showed that feelings of students about their accounting performance were more positive; their time management was developed and the flipped classroom method was preferred by the majority of the students who took survey.

Jusohand Ahmad (2016: 71)'s study aimed to examine the usage of iMindMap software as an interactive tool in the teaching and learning method especially for accounting students and to be able to think of iMindMap as an alternative instrument in getting the ultimate learning outputs. According to Jusoh and Ahmad (2016: 71)'s study, the majority of the students admitted that the 
attraction of iMindMap was more than the attraction of traditional teaching methods.

The aim of Arsoy, Bora and Selimoğlu (2014: 123)'s study was to present the knowledge, skills and education techniques required in accounting education in terms of academicians and professional accountants. The results of Arsoy et. al (2014: 127, 129-130)'s study showed that the first five subjects to be included in accounting education were financial accounting, analysis of financial statements, international accounting standards/international financial reporting standards, tax issues and external auditing according to the common opinion of academicians and professional accountants; the first five skills to be up skilled through accounting education were respectively analytical/critical thinking, correct professional attitude development, calculation techniques, written communication and motivation according to the common opinion of academicians and professional accountants; case studies, information analysis technique, technology usage based homework were the education techniques to be used in accounting education and role play was seen as education technique having the lowest significance according to both common and individually opinion of academicians and professional accountants.

Çukacı and Elagöz (2006), compared the teaching methods used in accounting courses of a faculty with teaching methods obtained from scientific researches and found that oral explanations and case studies were preferred mostly.

Angay Kutluk, Dönmez and Gülmez (2015)'s study to determine the preferred teaching techniques found that the best method to understand the accounting lessons was using powerpoint presentation and blackboard together. Students also thought that questions should be solved after explanation of the theoretical accounting lesson, and case studies about accounting should be used.

Tazegül, Kutlu and Elyıldırım (2014) examined student centered approaches used in accounting education and found that the most featured topics were providing students to participate in accounting courses, allowing adequate time for the topics to be better learnt and using computer packet programs to increase personally interaction.

\section{Materials and Methods}

The population of this study is Summer School students who have chosen Accounting courses in 2017 summer at Akdeniz University: Faculty of Economics and Administrative Sciences of Akdeniz University and other universities, faculty of applied Sciences of Akdeniz University, Tourism Faculty of Akdeniz University and other faculties of Akdeniz University and other universities. There were 4 different courses about Accounting in 2017 Summer: General Accounting I, General Accounting II, Cost Accounting and Management Accounting. Some students have chosen more than one type of Accounting courses. Data collection method is nonrandom sampling. There were747 students at the summer School of Akdeniz University in 2017(Students who have chosen more than one course are considered by checking attendance list). A survey is prepared and conducted to the students during accounting lessons. 303 surveys are obtained (Rate of return is $40,6 \%$ ). The survey is organized by the authors of this paper and by previous studies (Çukacı and Elagöz, 2006; Mısırlığlu, 2008; Tazegül et al., 2014; Kutluk et al., 2015) related to accounting teaching techniques. 
Survey includes demographic questions such as gender, age, their university, etc; general situation in summer school such as the number and type of the courses taken and questions about opinions such as contribution of the accounting courses they took in Summer School, reason to fail; the method that they understand accounting better. Frequencies of the questions and the results of chisquare analysis to show the relation between some variables are shown in Tables.

\section{Results and Discussions}

Frequencies of the questions are shown in tables and the highest or the most remarkable percent of them are stated under the tables. Chi-Square test results are shown in Tables.

As shown in Table 1, most of the students are male (52,1\%), 20-24 years old (79,2 \%), graduated from gymnasium (43,9\%) and from Akdeniz University Faculty of Economics and Administrative Sciences $(51,2 \%)$. Only 11, $6 \%$ of students have working experience in accounting and 33,7 \% of students are working during summer school. Only 34,0\% of students wants to choose accounting profession or work in a department related to accounting after graduation. 42,6\% of students spend time only before examinations on weekly basis for learning accounting courses.

Table 1: Frequencies of Demographic Questions

\begin{tabular}{|l|l|l|}
\hline Gender & Frequency & $\mathbf{\%}$ \\
\hline Female & 145 & 47,9 \\
\hline Male & 158 & 52,1 \\
\hline Total & 303 & 100,0 \\
\hline Age & Frequency & $\mathbf{\%}$ \\
\hline$<20$ & 30 & 9,9 \\
\hline $20-24$ & 240 & 79,2 \\
\hline$>24$ & 33 & 10,9 \\
\hline Total & 303 & 100,0 \\
\hline Type of graduated Gymnasium & Frequency & $\mathbf{\%}$ \\
\hline Gymnasium & 133 & 43,9 \\
\hline Anatolian or super high school & 115 & 38,0 \\
\hline Vocational high school & 13 & 4,3 \\
\hline Other & 42 & 13,9 \\
\hline Total & 303 & 100,0 \\
\hline University/Faculty & Frequency & $\mathbf{\%}$ \\
\hline Akdeniz-FEAS & 155 & 51,2 \\
\hline Akdeniz-FAP & 30 & 9,9 \\
\hline Akdeniz-Tourism & 55 & 18,2 \\
\hline Other Universities-FEAS & 51 & 16,8 \\
\hline Other Universities-Other Faculty & 12 & 4,0 \\
\hline Total & 303 & 100,0 \\
\hline Working experience in Accounting & Frequency & $\mathbf{\%}$ \\
\hline Yes & 35 & 11,6 \\
\hline No & 268 & 88,4 \\
\hline Total & 303 & 100,0 \\
\hline & & \\
\hline
\end{tabular}




\begin{tabular}{|l|l|l|}
\hline Working during Summer School & Frequency & $\mathbf{\%}$ \\
\hline Yes & 102 & 33,7 \\
\hline No & 201 & 66,3 \\
\hline Total & 303 & 100,0 \\
\hline $\begin{array}{l}\text { Choosing accounting profession or working in } \\
\text { a department related to accounting after } \\
\text { graduation }\end{array}$ & Frequency & $\mathbf{\%}$ \\
\hline Yes & 103 & \\
\hline No & 200 & 34,0 \\
\hline Total & 303 & 66,0 \\
\hline $\begin{array}{l}\text { Average amount of time spent on weekly basis } \\
\text { for learning accounting courses }\end{array}$ & Frequency & 100,0 \\
\hline Only before examinations & 129 & $\mathbf{\%}$ \\
\hline Less than 1 hour & 45 & 42,6 \\
\hline 1-3 hours & 105 & 14,9 \\
\hline More than 4 hours & 24 & 34,7 \\
\hline Total & 303 & 7,9 \\
\hline & & 100,0 \\
\hline
\end{tabular}

Table 2: Frequencies about General Situation in Summer School

\begin{tabular}{|l|l|l|}
\hline Number of the accounting courses taken in summer school & Frequency & $\mathbf{\%}$ \\
\hline 1 & 181 & 59,7 \\
\hline 2 & 90 & 29,7 \\
\hline 3 & 20 & 6,6 \\
\hline 4 & 12 & 4,0 \\
\hline Total & 303 & 100,0 \\
\hline Type of taking courses & Frequency & $\mathbf{\%}$ \\
\hline All of them from previous semester & 243 & 80,2 \\
\hline All of them from next semester & 14 & 4,6 \\
\hline Both from previous and next semester & 13 & 4,3 \\
\hline Extended student (in the 5th or more year of the education) & 33 & 10,9 \\
\hline Total & 303 & 100,0 \\
\hline Taking any "Accounting" course in summer school in previous years & Frequency & $\mathbf{\%}$ \\
\hline No & 194 & 64,0 \\
\hline Taken and passed & 47 & 15,5 \\
\hline Taken and failed & 62 & 20,5 \\
\hline Total & 303 & 100,0 \\
\hline Taking "General Accounting I" course during summer school & Frequency & $\mathbf{\%}$ \\
\hline Yes & 117 & 38,6 \\
\hline No & 186 & 61,4 \\
\hline Total & 303 & 100,0 \\
\hline Taking "general accounting II" course during summer school & Frequency & $\mathbf{\%}$ \\
\hline Yes & 167 & 55,1 \\
\hline No & 136 & 44,9 \\
\hline Total & 303 & 100,0 \\
\hline Taking "cost accounting course" during summer school & Frequency & $\mathbf{\%}$ \\
\hline & & \\
\hline
\end{tabular}




\begin{tabular}{|l|l|l|}
\hline Yes & 91 & 30,0 \\
\hline No & 212 & 70,0 \\
\hline Total & 303 & 100,0 \\
\hline Taking “management accounting” course during summer school & Frequency & $\mathbf{\%}$ \\
\hline Yes & 56 & 18,5 \\
\hline No & 247 & 81,5 \\
\hline Total & 303 & 100,0 \\
\hline
\end{tabular}

According to Table 2, most of the students took 1 course $(59,7 \%)$ and mostly from previous semester (80,2 \%). 64,0\% of students did not take any "Accounting" course in summer school in previous years. 38,6\% of students took "General Accounting I" course, 55,1\% of students took "General Accounting II" course, 30,0 \% of students took "Cost Accounting" course and 18,5\% of students took "Management Accounting" course during summer school.

Table 3: Frequencies about Method of Understanding Accounting Courses

\begin{tabular}{|c|c|c|c|}
\hline \multicolumn{2}{|l|}{$\begin{array}{l}\text { Method of understanding theoretical part of "Accounting" courses } \\
\text { best }\end{array}$} & Frequency & $\%$ \\
\hline \multicolumn{2}{|l|}{ Blackboard } & 106 & 35,0 \\
\hline \multicolumn{2}{|l|}{ Power-point presentation } & 32 & 10,6 \\
\hline \multicolumn{2}{|l|}{ Blackboard and power-point presentation together } & 158 & 52,1 \\
\hline \multicolumn{2}{|l|}{ Smart board } & 7 & 2,3 \\
\hline \multicolumn{2}{|l|}{ Total } & 303 & 100,0 \\
\hline \multicolumn{2}{|l|}{$\begin{array}{l}\text { Method of understanding practical/exercise part of "accounting" } \\
\text { courses best }\end{array}$} & Frequency & $\%$ \\
\hline \multicolumn{2}{|l|}{ Blackboard } & 165 & 54,5 \\
\hline \multicolumn{2}{|l|}{ Power-point presentation } & 20 & 6,6 \\
\hline \multicolumn{2}{|l|}{ Blackboard and power-point presentation together } & 113 & 37,3 \\
\hline \multicolumn{2}{|l|}{ Smart board } & 5 & 1,7 \\
\hline \multicolumn{2}{|l|}{ Total } & 303 & 100,0 \\
\hline \multicolumn{2}{|l|}{ Method of understanding "accounting courses" better } & Frequency & $\%$ \\
\hline \multirow{3}{*}{$\begin{array}{l}\text { Journal entries/practices/exercises should be taught on } \\
\text { blackboard }\end{array}$} & Yes & 188 & 62,0 \\
\hline & No & 115 & 38,0 \\
\hline & Total & 303 & 100,0 \\
\hline \multirow{3}{*}{$\begin{array}{l}\text { Journal entries/practices/exercises should be taught by power- } \\
\text { point }\end{array}$} & Yes & 33 & 10,9 \\
\hline & No & 270 & 89,1 \\
\hline & Total & 303 & 100,0 \\
\hline \multirow[t]{3}{*}{ Case studies should be used } & Yes & 174 & 57,4 \\
\hline & No & 129 & 42,6 \\
\hline & Total & 303 & 100,0 \\
\hline \multirow{3}{*}{$\begin{array}{l}\text { Quizzes should be made sometimes to ensure me study } \\
\text { regularly }\end{array}$} & Yes & 47 & 15,5 \\
\hline & No & 256 & 84,5 \\
\hline & Total & 303 & 100,0 \\
\hline \multirow{3}{*}{$\begin{array}{l}\text { Students should be encouraged to solve question on } \\
\text { blackboard }\end{array}$} & Yes & 43 & 14,2 \\
\hline & No & 260 & 85,8 \\
\hline & Total & 303 & 100,0 \\
\hline
\end{tabular}




\begin{tabular}{|l|l|l|l|}
\hline Students should be grouped to present the accounting subjects & Yes & 39 & 12,9 \\
\cline { 2 - 3 } and examples & No & 264 & 87,1 \\
\cline { 2 - 3 } & Total & 303 & 100,0 \\
\hline Course time should be enlarged & Yes & 9 & 3,0 \\
\cline { 2 - 3 } & No & 294 & 97,0 \\
\cline { 2 - 3 } & Total & 303 & 100,0 \\
\hline $\begin{array}{l}\text { Students should get the course notes before the lesson that } \\
\text { students could be prepared }\end{array}$ & Yes & 163 & 53,8 \\
\cline { 2 - 3 } & No & 140 & 46,2 \\
\cline { 2 - 3 } & Total & 303 & 100,0 \\
\hline
\end{tabular}

As shown in Table 3, 52,1\% of students can understand theoretical part of "accounting" courses best with blackboard and power-point presentation together and 54,5\% of students can understand practical/exercise part of "accounting" courses best with blackboard. In Can et al. (2012)'s study the best preferred way was teaching with blackboard and in Kutluk et al. (2015)'s study, the best way to understand better was by using blackboard and power-point presentation together. $62,0 \%$ of students state that journal entries/practices/exercises should be taught on blackboard. Conversely, $89,1 \%$ of students state that journal entries/practices/exercises should not be taught by power-point. According to 57,4 \% of students, case studies should be used but only $15,5 \%$ of students state that quizzes should be made sometimes to ensure them study regularly. Also in Çukacı and Elagöz (2006)'s study, case studies were from preferable teaching techniques. According to $85,8 \%$ of students, students should not be encouraged to solve question on blackboard and $87,1 \%$ of students state that students should not be grouped to present the accounting subjects and examples. Only 3,0\% of students state that course time should be enlarged. Conversely, 53,8\% of students state that students should get the course notes before the lesson that students could be prepared.

Table 4: Frequency of Contribution of the Accounting Courses Taken in Summer School to the Learning

\begin{tabular}{|l|l|l|}
\hline Contribution & Frequency & \% \\
\hline Its contribution is as same as in regular term & 99 & 32,7 \\
\hline Its contribution is less than in regular term & 26 & 8,6 \\
\hline Its contribution is more than in regular term & 178 & 58,7 \\
\hline Total & 303 & 100,0 \\
\hline
\end{tabular}

As shown in Table 4, 58,7\% of students state that contribution of the "Accounting" courses taken in summer school to the learning is more than in regular term.

Table 5: Frequencies about the Reasons for Choosing Summer School

\begin{tabular}{|l|l|l|}
\hline To graduate earlier & Frequency & $\mathbf{\%}$ \\
\hline Yes & 28 & 9,2 \\
\hline No & 275 & 90,8 \\
\hline Total & 303 & 100,0 \\
\hline To pass the failed courses & Frequency & $\mathbf{\%}$ \\
\hline Yes & 244 & 80,5 \\
\hline No & 59 & 19,5 \\
\hline Total & 303 & 100,0 \\
\hline
\end{tabular}




\begin{tabular}{|l|l|l|}
\hline Summer School is a better alternative while working & Frequency & $\mathbf{\%}$ \\
\hline Yes & 25 & 8,3 \\
\hline No & 278 & 91,7 \\
\hline Total & 303 & 100,0 \\
\hline Couldn't attend to the course in regular term & Frequency & $\mathbf{\%}$ \\
\hline Yes & 78 & 25,7 \\
\hline No & 225 & 74,3 \\
\hline Total & 303 & 100,0 \\
\hline
\end{tabular}

Table 5 shows that main reason for choosing summer school is to pass the failed courses $(80,5 \%)$ and second important reason is that students could not attend to course in regular term $(25,7 \%)$. Only $9,2 \%$ of students chose summer school to graduate earlier.

Table 6: Frequencies about the Reasons for Failing from Accounting course/courses during the Semester

\begin{tabular}{|l|l|l|}
\hline Didn't study enough & Frequency & $\mathbf{\%}$ \\
\hline Yes & 155 & 51,2 \\
\hline No & 148 & 48,8 \\
\hline Total & 303 & 100,0 \\
\hline Can't understand accounting & Frequency & $\%$ \\
\hline Yes & 133 & 43,9 \\
\hline No & 170 & 56,1 \\
\hline Total & 303 & 100,0 \\
\hline Didn't attend to course regularly & Frequency & $\mathbf{\%}$ \\
\hline Yes & 107 & 35,3 \\
\hline No & 196 & 64,7 \\
\hline Total & 303 & 100,0 \\
\hline The lecturer taught very quickly & Frequency & $\mathbf{\%}$ \\
\hline Yes & 59 & 19,5 \\
\hline No & 244 & 80,5 \\
\hline Total & 303 & 100,0 \\
\hline Couldn't understand the type of teaching of the lecturer & Frequency & $\mathbf{\%}$ \\
\hline Yes & 108 & 35,6 \\
\hline No & 195 & 64,4 \\
\hline Total & 303 & 100,0 \\
\hline Hesitated to ask the lecturer what I couldn't understand & Frequency & $\mathbf{\%}$ \\
\hline Yes & 34 & 11,2 \\
\hline No & 269 & 88,8 \\
\hline Total & 303 & 100,0 \\
\hline $\begin{array}{l}\text { Couldn't understand the practices/exercise because the lecture was } \\
\text { given by power-point }\end{array}$ & Frequency & $\mathbf{\%}$ \\
\hline Yes & 4 & \\
\hline No & 499 & 1,3 \\
\hline Total & 303 & 98,7 \\
\hline & & 100,0 \\
\hline
\end{tabular}




\begin{tabular}{|l|l|l|}
\hline $\begin{array}{l}\text { Didn't fail the course, I take the course from the next semester in } \\
\text { summer school }\end{array}$ & Frequency & $\mathbf{\%}$ \\
\hline Yes & 18 & 5,9 \\
\hline No & 285 & 94,1 \\
\hline Total & 303 & 100,0 \\
\hline
\end{tabular}

According to Table 6, main reasons for failing from accounting course/courses during the semester are that students did not study enough $(51,2 \%)$ and students could not understand accounting $(43,9$ $\%)$. Other important reasons are that students could not understand the type of teaching of the lecturer $(35,6 \%)$ and students did not attend to course regularly $(35,3 \%)$.

Table 7: Relation between Choosing Summer School to Pass the Failed Courses and Failing from Accounting Course/Courses during the Semester because of not Studying Enough

\begin{tabular}{|c|c|c|c|c|c|c|c|}
\hline \multicolumn{2}{|l|}{$\chi^{2}=5,638, p=0,018(<0,05)$} & \multicolumn{4}{|c|}{$\begin{array}{l}\text { Failing from accounting course/courses } \\
\text { during the semester because of not studying } \\
\text { enough }\end{array}$} & \multirow{2}{*}{\multicolumn{2}{|c|}{ Total }} \\
\hline \multirow{5}{*}{$\begin{array}{l}\text { Choosing summer } \\
\text { school to pass the failed } \\
\text { courses }\end{array}$} & & \multicolumn{2}{|c|}{ Yes } & \multicolumn{2}{|l|}{ No } & & \\
\hline & & $\mathbf{N}$ & $\%$ & $\mathbf{N}$ & $\%$ & $\mathbf{N}$ & $\%$ \\
\hline & Yes & 133 & 55 & 111 & 45 & 244 & 100 \\
\hline & No & 22 & 37 & 37 & 63 & $\begin{array}{l}59 \\
\end{array}$ & 100 \\
\hline & Total & 155 & 51 & 148 & 49 & 303 & 100 \\
\hline
\end{tabular}

As shown in Table 7, there is relation between choosing summer school to pass the failed courses and failing from accounting course/courses during the semester because of not studying enough. Students, who chose summer school to pass the failed courses, think more, that they failed from accounting course/courses during the semester because of not studying enough.

Table 8: Relation between Failing from Accounting Course/Courses during the Semester because of not Understanding Accounting and Contribution of the Accounting Courses Taken in Summer School to the Learning

\begin{tabular}{|c|c|c|c|c|c|c|c|c|c|}
\hline \multicolumn{2}{|l|}{$\chi^{2}=8,362, \mathrm{p}=0,015(<0,05)$} & \multicolumn{6}{|c|}{$\begin{array}{l}\text { Contribution of the general } \\
\text { accounting courses taken in summer } \\
\text { school to the learning }\end{array}$} & \multirow{2}{*}{\multicolumn{2}{|c|}{ Total }} \\
\hline \multirow{5}{*}{$\begin{array}{l}\text { Failing from accounting } \\
\text { course/courses during the } \\
\text { semester because of not } \\
\text { understanding accounting }\end{array}$} & & \multicolumn{2}{|c|}{$\begin{array}{l}\text { As same as } \\
\text { in Regular } \\
\text { term }\end{array}$} & \multicolumn{2}{|c|}{$\begin{array}{l}\text { Less than } \\
\text { in Reg. } \\
\text { term }\end{array}$} & \multicolumn{2}{|c|}{$\begin{array}{l}\text { More than } \\
\text { in Regular } \\
\text { term }\end{array}$} & & \\
\hline & & $\mathrm{N}$ & $\%$ & $\mathrm{~N}$ & $\%$ & $\mathrm{~N}$ & $\%$ & $\mathbf{N}$ & $\%$ \\
\hline & Yes & 52 & 39 & 15 & 11 & 66 & 50 & 133 & 100 \\
\hline & No & 47 & 28 & 11 & 6 & 112 & 66 & 170 & 100 \\
\hline & Total & 99 & 33 & 26 & 9 & 178 & 58 & 303 & 100 \\
\hline
\end{tabular}

As shown in Table 8, there is relation between failing from accounting course/courses during the semester because of not understanding accounting and contribution of the accounting courses taken in summer school to the learning. Students, who think that they failed from accounting course/courses during the semester because of not understanding accounting believe that 
contribution of the accounting courses taken in summer school to the learning is more than in regular term and as same as regular term respectively.

Table 9: Relation between Failing from Accounting Course/Courses during The Semester because of not Attending to Course Regularly and Contribution of the Accounting Courses Taken in Summer School to the Learning

\begin{tabular}{|c|c|c|c|c|c|c|c|c|c|}
\hline \multicolumn{2}{|l|}{$\chi^{2}=8,814, \mathrm{p}=0,012(<0,05)$} & \multicolumn{6}{|c|}{$\begin{array}{l}\text { Contribution of the accounting } \\
\text { courses taken in summer school to the } \\
\text { learning }\end{array}$} & \multirow{2}{*}{\multicolumn{2}{|c|}{ Total }} \\
\hline \multirow{5}{*}{$\begin{array}{l}\text { Failing from accounting } \\
\text { course/courses during the } \\
\text { semester because of not } \\
\text { attending to course regularly }\end{array}$} & & \multicolumn{2}{|c|}{$\begin{array}{l}\text { As same as } \\
\text { in Regular } \\
\text { term }\end{array}$} & \multicolumn{2}{|c|}{$\begin{array}{l}\text { Less than } \\
\text { in Reg. } \\
\text { term }\end{array}$} & \multicolumn{2}{|c|}{$\begin{array}{l}\text { More than } \\
\text { in Regular } \\
\text { term }\end{array}$} & & \\
\hline & & $\mathbf{N}$ & $\%$ & $\mathbf{N}$ & $\%$ & $\mathbf{N}$ & $\%$ & $\mathbf{N}$ & $\%$ \\
\hline & Yes & 25 & 23 & 7 & 7 & 75 & 70 & 107 & 100 \\
\hline & No & 74 & 38 & 19 & 10 & 103 & 52 & 196 & 100 \\
\hline & Total & 99 & 33 & 26 & 8 & 178 & 59 & 303 & 100 \\
\hline
\end{tabular}

As shown in Table 9, there is relation between failing from accounting course/courses during the semester because of not attending to course regularly and contribution of the accounting courses taken in summer school to the learning. Students, who think that they failed from accounting course/courses during the semester because of not attending to course regularly believe that contribution of the general accounting courses taken in summer school to the learning is more than in regular term and as same as in regular term respectively.

Table 10: Relation between Failing from Accounting Course/Courses during The Semester because of not Understanding Accounting and Teaching Journal Entries/Practices/Exercises on Blackboard

\begin{tabular}{|c|c|c|c|c|c|c|c|}
\hline \multirow{2}{*}{\multicolumn{2}{|c|}{$\chi^{2}=5,159, \mathrm{p}=0,023(<0,05)$}} & \multicolumn{4}{|c|}{ Teaching journal } & \multirow{2}{*}{\multicolumn{2}{|c|}{ Total }} \\
\hline & & \multicolumn{4}{|c|}{ blackboard } & & \\
\hline \multirow{5}{*}{$\begin{array}{l}\text { Failing from accounting } \\
\text { course/courses during the semester } \\
\text { because of not understanding } \\
\text { accounting }\end{array}$} & & \multicolumn{2}{|c|}{ Yes } & \multicolumn{2}{|l|}{ No } & & \\
\hline & & $\mathbf{N}$ & $\%$ & $\mathbf{N}$ & $\%$ & $\mathbf{N}$ & $\%$ \\
\hline & Yes & 73 & 55 & 60 & 45 & 133 & 100 \\
\hline & No & 115 & 68 & 55 & 32 & 170 & 100 \\
\hline & Total & 188 & 62 & 115 & 38 & 303 & 100 \\
\hline
\end{tabular}

As shown in Table 10, there is relation between failing from accounting course/courses during the semester because of not understanding accounting and teaching journal entries/practices/exercises on blackboard. Students, who think that they failed from accounting course/courses during the semester because of not understanding accounting think that they can understand better if journal entries/practices/exercises should be taught on blackboard. 
Table 11: Relation between Failing from Accounting Course/Courses during The Semester because of not Understanding Accounting and Teaching Journal Entries/Practices/Exercises by Power-point

\begin{tabular}{|c|c|c|c|c|c|c|c|}
\hline \multicolumn{2}{|l|}{$\chi^{2}=7,798, p=0,005(<0,05)$} & \multicolumn{4}{|c|}{$\begin{array}{lr}\text { Teaching journal } \\
\text { entries/practices/exercises } \\
\text { power-point }\end{array}$} & \multicolumn{2}{|c|}{ Total } \\
\hline \multirow{5}{*}{$\begin{array}{l}\text { Failing from } \text { accounting } \\
\text { course/courses during the semester } \\
\text { because of not understanding } \\
\text { accounting }\end{array}$} & & \multicolumn{2}{|c|}{ Yes } & \multicolumn{2}{|c|}{ No } & & \\
\hline & & $\mathbf{N}$ & $\%$ & $\mathbf{N}$ & $\%$ & $\mathbf{N}$ & $\%$ \\
\hline & Yes & 22 & 17 & 111 & 83 & 133 & 100 \\
\hline & No & 11 & 6 & 159 & 94 & 170 & 100 \\
\hline & Total & 33 & 11 & 270 & 89 & 303 & 100 \\
\hline
\end{tabular}

As shown in Table 11, there is relation between failing from accounting course/courses during the semester because of not understanding accounting and teaching journal entries/practices/exercises by power-point. Students, who think that they failed from accounting course/courses during the semester because of not understanding accounting, think that they can't understand better if journal entries/practices/exercises should be taught by power-point.

\section{Conclusions and Recommendations}

The aim of this study is to investigate the reasons why the students fail in accounting courses and which teaching techniques may help them to understand accounting better. The main reason to fail Accounting lessons was that they didn't study enough. Also almost half of the students stated that they can't understand accounting. The best method of understanding theoretical part of "Accounting" courses is using blackboard and power-point presentation together; and the best method of understanding practical/exercise part of "Accounting" courses is using blackboard. More than half of the students think case studies should be used and they should get the course notes before lessons to be prepared. Most of the students have chosen Summer School to pass the failed courses and more than half of them think that the contribution of Summer School is more than in regular term.

For the first research question of whether there is a relationship between the reason to choose summer school and the reason to fail accounting courses, results showed that students who chose summer school to pass the failed courses, think more that they failed from accounting course/courses during the semester because of not studying enough. For the second research question of whether there is a relationship between the reason to fail accounting courses and contribution of accounting courses taken in summer school, the results showed that students who think that they failed from accounting course/courses during the semester because of not understanding accounting and because of not attending to course regularly believe that contribution of the accounting courses taken in summer school to the learning is more than in regular term and as same as regular term respectively. For the third research question of whether there is a relationship between the reason to fail accounting courses the method to understand the accounting course better, results showed that students who think that they failed from accounting course/courses during the semester because of not understanding accounting think that they can understand better if journal entries/practices/exercises should be taught on blackboard, but they think they can't understand if they are taught by powerpoint presentation. 
Some of the students of business programs will be future accountants or some of them will be nonaccountants who will need accounting knowledge as being an important information source in business. Hence, teaching accounting aims to provide them to use knowledge in decision making, analysing and interpreting and bring innovation to their job in consideration of the developments (Yürekli and Gönen, 2015, 313). The results of the study show that students don't have much interest in accounting courses as they have expressed that they didn't study enough or can't understand. One of the reasons may be their belief that accounting may be difficult. Another reason may be because the teaching ways aren't attractive. Other teaching techniques that are mentioned in literature review part of this study can be considered. Misırlığlu (2008, p. 33) states that smallgroup teaching is more effective way and suggested some effective teaching characteristics such as structuring the goals in lecture series preparation, conversation with students and allowing more group-based teaching time.

Updating the curriculum, searching more understandable teaching techniques and getting feedback from students and lecturers are some ways to be improved and preferable for universities that will bring prestige in competitive context.

The limitation of this study is that it is performed in a Summer School program of a university. It is suggested to perform this research in different universities and faculties during regular semesters to compare the results.

\section{References}

[1] Indra Abeysekera. (2015). "Student Preferences for Instructional Methods in An Accounting Curriculum." International Journal of Teaching and Learning in Higher Education, 27(3), 310-319. Http://Www.Isetl.Org/Ijtlhe/Pdf/Ijtlhe2001.Pdf.

[2] Nergis Nalan Altıntaş, Ayça Zeynep Süer, Emre Selçuk Sarı And Miraç Sema Ülker. (2014). "The Use of Poster Projects as A Motivational and Learning Tool in Managerial Accounting Courses." Journal of Education for Business, 89(4), 196-201. Https://Doi.Org/10.1080/08832323.2013.840553.

[3] Filiz Angay Kutluk, Adnan Dönmez And Mustafa Gülmez. (2015). “Opinions of University Students About Teaching Techniques in Accounting Lessons." Procedia - Social and Behavioral Sciences 191, 1682 - 1689. Https://Doi.Org/10.1016/J.Sbspro.2015.04.155.

[4] Aylin Poroy Arsoy, Tuba Bora and Seval Selimoğlu. (2014). "Muhasebe Eğitimindeki Bilgi, Beceri Ve Eğitim Tekniklerinin Gerekliliklerine İlişkin Beklentiler: Türkiye'deki Akademisyenlere Ve Meslek Mensuplarına Yönelik Bir Araştırma." Uluslararası Yönetim İktisat Ve İ̧̧letme Dergisi, 10(23), 121-136. Http://Dx.Doi.Org/10.17130/Ijmeb.2014.10.23.479.

[5] A.Vecdi Can, Nevran Karaca, Nermin Akyel And S. Doğuş Demirci. (2012). "Evaluating the Fitness Of Lecturing With Power point presentations For Accounting Education- Research At Sakarya university." Procedia - Social and Behavioral Sciences, 55, 128-137. Https://Doi.Org/10.1016/J.Sbspro.2012.09.486.

[6] Bea Chiang, Hossein Nouri And Subarna Samanta. (2014). "The Effects of Different Teaching Approaches In Introductory Financial Accounting." Accounting Education, 23(1), 42-53. Https://Doi.Org/10.1080/09639284.2013.833724.

[7] Chei-Chang Chiou, Li-Tze Lee, Li-Chu Tien And Yu-Min Wang. (2017). "Analyzing the Effects Of Various Concept Mapping Techniques On Learning Achievement Under Different Learning Styles." Eurasia Journal of Mathematics, Science \& Technology Education, 13(7), 3687-3708. Https://Doi.Org/10.12973/Eurasia.2017.00753a. 
[8] Yusuf Cahit Çukacı and İsmail Elagöz, İ. (2006). "Muhasebe Derslerinde Kullanılan Öğretim Yöntemleri İle Öğrenme Stillerinin İlişkisinin Ortaya Konulması Ve Dokuz Eylül Üniversitesi İktisadi Ve İdari Bilimler Fakültesi’nde Bir Uygulama.” D.E.Ü.İ.̇.B.F.Dergisi, 21(1), 147-164. Https://Iibfdergi.Deu.Edu.Tr/Index.Php/Cilt1-Sayi1/Article/View/199/Pdf_182.

[9] Yasemin Ertan, Elif Yücel And Mehlika Saraç. (2014). "Kavram Haritaları Tekniğinin Muhasebe Eğitiminde Kullanılması: Uludağ Üniversitesi Uygulaması.” Business and Economics Research Journal, 5(1), 107-122. Http://Www.Berjournal.Com/Wp-Content/Plugins/DownloadsManager/Upload/Berj\%205(1)14\%20article\%206.Pdf.

[10] Suresh L. Gamlath. (2007). "Outcomes and Observations of An Extended Accounting Board Game. Developments in Business Simulation and Experiential Learning." Developments in Business Simulation and Experiential Learning, 34, 132-137. Https://Journals.Tdl.Org/Absel/Index.Php/Absel/Article/View/454/418.

[11] Umar Inuwa, Zarifah Abdullah And Haslinda Hassan. (2017). "Assessing the Effect of Cooperative Learning on Financial Accounting Achievement Among Secondary School Students." International Journal of Instruction, 10(3), 31-46. Https://Doi.Org/10.12973/Iji.2017.1033a.

[12] Wan Noor Hazlina Wan Jusoh And Suraya Ahmad. (2016). "Imindmap As an Innovative Tool in Teaching and Learning Accounting: An Exploratory Study." Interactive Technology and Smart Education, 13(1), 71-82. Https://Doi.Org/10.1108/Itse-05-2015-0012.

[13] E. Lubbe. (2016). "Innovative Teaching in Accounting Subjects: Analysis of The Flipped Classroom." International Journal of Social Sciences and Humanity Studies, 8(2), 63-74. Http://Www.Sobiad.Org/Ejournals/Journal_Ijss/Arhieves/Ijss2016_2/Paper33_Lubbe.Pdf.

[14] Nevine Sobhy Abdel Megeid. (2014). "E-Learning Versus Blended Learning in Accounting Courses." The Quarterly Review of Distance Education, 15(2), 35-55.

Http://Eds.B.Ebscohost.Com/Eds/Pdfviewer/Pdfviewer?Vid=0\&Sid=87329c53-C3c4-4376-94bb7982e40f035c\%40sessionmgr104.

[15] İsmail Ufuk Misırlığlu. (2008). "Teaching and Learning Experience in Accounting Education: A Uk Perspective.” Muhasebe Bilim Dünyası Dergisi(Mödav), 10(4), 19-35.

Http://Eds.B.Ebscohost.Com/Eds/Pdfviewer/Pdfviewer?Vid=0\&Sid=9a1ec0a9-3afe-4ea8-A5c6881d7abdedb4\%40pdc-V-Sessmgr03.

[16] Ana Maria Beatriz Sardela, Patrícia De Souza Costa And Gilvania De Sousa Gomes. (2017). "Theory in The Picture: Video Production as A Tool In Accounting Teaching." Revista De Educação E Pesquisaemcontabilidade, 11(2), 164-186.

Http://Dx.Doi.Org/10.17524/Repec.V11i2.1523.

[17] Banu Sultanoğlu, Ceren Aydoğmuş, And Nazlı Akman. (2014). "Muhasebe Eğitiminde Tablolama (Excel) Uygulamasının Öğrenci Başarısı Üzerindeki Etkisi." Muhasebe Bilim Dünyası Dergisi(Mödav), 16(3), 97-111. Http://Eds.B.Ebscohost.Com/Eds/Pdfviewer/Pdfviewer?Vid=0\&Sid=Dd5cea7f-9e2c-461c-8a31Da6a814f2406\%40pdc-V-Sessmgr05.

[18] Alper Tazegül, Hüseyin Ali Kutlu Ümit Yaşar Elyıldırım. (2014). "Yeni Yaklaşımlar Ve ÖğrenmeÖğretme Etkinlikleri-Muhasebe Öğretiminde Öğrenci Merkezli Yöntemler Ve Araçlar.” 33. Türkiye Muhasebe Eğitimi Sempozyumu Bildiriler Kitab1, 31-53.

[19] Emin Yürekli And Seçkin Gönen. (2015). "Muhasebe Meslek Mensuplarının Nitelikli Meslek Mensubu Yetiştirilmesine Yönelik Önlisans Programından Beklentileri.” Kaü İibf Dergisi, 6(10), 301-316.

*Corresponding author.

E-mail address: angay@ akdeniz.edu.tr 